\title{
Asset-Based Reserve Requirements: A New Monetary Policy Instrument for Targeting Diverging Real Estate Prices in the Euro Area
}

\author{
Michael Holz*
}

Can monetary policy prevent real estate bubbles from harming economic welfare? The European Central Bank (ECB) has to conduct monetary policy for the Euro area as a whole, but her policy affects countries with rapidly rising house prices (e.g. Spain) in a markedly different way than those with stagnating house prices (like Germany). For opposing divergent real estate price developments within the European Monetary Union (EMU), interest rate policy is not the appropriate instrument; whereas "fine tuning" may be possible with the help of asset-based reserve requirements. All financial institutions would be forced to deposit them at the ECB (as a percentage of asset holdings). Reserve rates are free to vary between countries. Therefore, rates should be highest in those countries where appropriate indicators signal a house price bubble.

JEL classifications: E44, E52, GI8

Keywords: monetary policy, real estate prices, Tobin's $Q$, minimum reserve policy, financial stability

\section{The Relevance of Asset Prices for the Conduct of Monetary Policy}

„Developments in residential property prices are an important factor underlying monetary policy decisions aimed at maintaining price stability in the euro area over the medium term. For example, changes in residential property prices may affect households' consumption behaviour, in particular through wealth effects, as well

* University of Trier.

Correspondence Address:

Dr. Michael Holz, University of Trier, FB IV - Economics (Money, Credit, Currency), Universitätsring I5, 54296 Trier, Germany, e-mail: holzm@uni-trier.de

Received Io Jan 2007, accepted 30 Apr 2007

(C) INTERVENTION 4 (2), 2007, 33I-35I 
as residential investment. [...] The importance of residential property price developments from a monetary policy perspective also reflects the high economic costs which can be associated with the formation and subsequent bursting of house price bubbles." (ECB 2006a: 55)

This ECB statement from February 2006 of course is not new per se, regarding the contemporary economic literature, but it is new with respect to the ECB monetary policy framework, and because it might reveal that it is inclined to carry out a paradigm change in the near future. Only four years earlier, in February 2002, which was an episode of collapsing stock prices following the "New Economy Boom", the echo from the euro tower in Frankfurt was quite different:

"The above notwithstanding, it should be stressed that stock prices are not a suitable goal for monetary policy. First, monetary policy cannot control stock prices over the long term. [...] Second, while monetary policy might have some shortterm impact on stock prices, it is impossible for monetary policy to control stock prices in any precise manner over the short term [...] Finally, if monetary policy were focused on stock market developments, the public's perception as to the commitment of the central bank to its primary objective of maintaining price stability could become blurred.« (ECB 2002: 5of.)

Indeed, these are two different asset markets, but both asset categories - stocks and real estate - are main components of households' wealth. In many countries, the stock market boom during the second half of the I990s just preceded the housing boom for some years. Nevertheless, it should be noted that real estate is financed largely through mortgage loans, whilst stocks are bought through an expenditure of one's savings. As a matter of fact, this difference in the form of financing asset purchases is quite relevant for the implications of monetary policy decisions. What both markets have in common is the speculative element of investments, which times and again leads to a noticeable divergence between fundamental value and market price, eventually ending in a speculative bubble. Of course, the degree of speculative behaviour is higher in stock markets, because a considerable share of real estate investment is aimed at homeownership; but it is the remaining share of the housing market, which is dominated by institutional investors, that is responsible for the bulk of total real estate turnover.

By April 2007, according to many experts the Spanish housing market shows strong warning signs of a bursting bubble. Therefore, this article focuses on EMU real estate markets. Although the ECB has noticed an urgent need for monitoring housing markets, there are still open questions concerning the suitable monetary policy indicators for identifying misalignments timely, and about which are the right monetary policy instruments for fighting them.

For many years, the questions »if « and »how « a variation of central bank interest rates is suited for reacting to asset market misalignments have been open to controversy. Even monetary policy experience during the episode from 2000 to 2003 , following the burst of the stock price bubble, was not able to deliver a clear recipe for reaction, because the 
monetary policy response came quite late, only in the aftermath of the burst, in order to dampen the negative macroeconomic consequences and repercussions in the private and banking sector. There was no hint of preventive measures in the late I99os. Even in April 2005, the ECB wrote:

"However, a prudent policy response to a suspected asset price misalignment is unlikely to take the form of a simple reaction rule expanded by an asset price index." (ECB 2005: 59)

"Simple« rules are never anything more than abstract, rough guidelines, which have the merit of being easy to communicate to the public. Of course, asset pricing in financial markets cannot be controlled with the help of an interest rate policy based on mechanical rules. A comprehensive monetary analysis is needed. The ECB faces the task and problem to conduct a single monetary policy for the Euro area as a whole. Therefore, in contrast to the case of simultaneously rising stock prices in all EMU countries until 2000, interest rate policy is not the proper instrument for tackling diverging housing markets. A "fine tuning", however, may be possible with the help of Asset-Based Reserve Requirements (ABRRs).

Section 2 sketches house price trends in EMU countries from the start of monetary union in 1999 until today. Section 3 delivers a very short theoretical explanation of the interdependencies between monetary policy, asset prices, and economic activity, which is based on an extended version of James Tobin's macroeconomic portfolio theory. In Section 4 we present a proposal for designing a system of ABRRs in EMU countries suited for counterbalancing real estate bubbles. Section 5 describes bubble indicators and deducts appropriate national reserve rates. Section 6 concludes.

\section{House Price Trends in EMU Countries and Their Macroeconomic Consequences}

There are multiple reasons why a new monetary policy instrument, namely ABRRs, should be applied to real estate markets in EMU:

- While the stock markets ofEMU member countries have shown parallel ups and downs in the boom and bust period from 1997 until 2003, we have seen very different price trends in EMU housing markets since the introduction of the euro. From 1999 until the end of 2005, the average annual rise of house prices has been 15.2 percent in Spain and 13.5 percent in Ireland. Whereas in Germany prices stagnated, with an average annual loss of 0.6 percent (ECB 2006d: 64).

- This divergent development makes it costly (in terms of welfare loss) to find the right monetary policy interest rate reaction for the Euro area as a whole. ABRRs on the other hand enable the ECB to target different countries' real estate markets with different reserve rates. 
- Private sector housing wealth in EMU is much bigger than the part of financial wealth held in stocks. The share for housing/real estate (stocks) in total private net wealth is $5 \mathrm{I}$ percent (eight percent) in Germany, 49 percent (I4 percent) in Italy, 47 percent ( 13 percent) in France, and 64 percent (twelve percent) in Spain. In contrast to this, in the United States housing only stands for 27 percent of total wealth, whereas the direct holdings of stocks (excluding pension schemes) account for an equal share of 24 percent (Altissimo et al. 2005: $13 \mathrm{f}$.).

- According to this, the bust of a house price bubble would trigger much deeper negative macroeconomic effects for private consumption, GDP growth, and employment than the bursting of the technology stock bubble in the aftermath of the "New Economy Boom «. Empirical results show a distinctively higher marginal propensity to consume out of housing wealth, compared with the marginal propensity out of financial wealth (stocks and bonds).

- In addition, housing wealth in EMU countries is much more widespread than stock market wealth. While stocks are predominantly owned by higher income groups, housing wealth - financed via mortgage loans - shows a more even distribution. Especially the lower income groups would suffer from rapidly falling prices of their homes, because the restrictive effect on their consumption budget would be felt immediately (Altissimo et al. 2005: IIf., HM Treasury 2003, OECD 2005, van den Noord 2006).

- ECB studies have identified a high correlation between rising house prices and the expansion of mortgage credit in a panel of EMU countries. The annual average growth rate of mortgage loans from 1999 until 2004 was nearly 30 percent in Greece, about 25 percent in Ireland, and nearly 20 percent in Spain and Italy (ECB 2006b: 45 ff.).

- Part of this credit boom is surely due to the convergence process of long-term interest rates prior to the EMU start in 1999. On the other hand, the house price boom accelerated after 200I, a period of collapsing stock prices and only muted GDP growth, which forced the ECB to massively lower their key interest rates, making mortgage loans cheaper.

\section{The Post-Keynesian Transmission Mechanism: Monetary Policy, Asset Prices, and Economic Activity}

If asset prices are deemed to stand at the centre of a macroeconomic analysis, the role they play for the functioning of the economy has to be clarified first. Monetarists following Milton Friedman define five relevant asset categories (money, bonds, stocks, physical capital, and human capital) as perfect substitutes in private portfolios, generating identical marginal rates of return. Expectations are always right; all kinds of risk are irrelevant for decision. As a consequence, monetary policy simply has to focus on base money, following a »k percent rule» to foster price stability. 
In contradiction to this, in post-Keynesian theory expectations often turn out to be wrong. It was James Tobin's macroeconomic portfolio theory, which has at its heart the special role played by uncertainty and the trade-off between risk and return of different asset categories (Tobin 1969). Bank deposits are a financial asset that is generally the most liquid "abode«of purchasing power. Therefore, monetary policy can cause real economic effects through substitution effects and wealth effects. Tobin distinguishes two big blocks of assets: financial assets (money/deposits, bonds) and real assets (stocks and physical capital). Within each block, the assets are substitutes, but between the two blocks the relation is complementary according to their risk and return characteristics.

At the centre of Tobin's theory stands the comparison of two different rates of return: the »supply price of capital " and the "demand price of capital«, in other words the relation between marginal returns from new physical capital investment and the average return of the capital stock, known as »Tobin's $\mathrm{Q}$ «. In this concept, monetary policy can only influence the market price of the existing capital stock. If monetary policy action leads entrepreneurs to create new capital goods, because now Tobin's $Q$ is bigger than I, i.e. the market value surpasses the reproduction costs, this will cause higher investment at an economywide level and a rising GDP. Unfortunately, the transmission process is not always as perfect as in a neoclassical world, there are many obstacles leading monetary policy to miss its targets for GDP growth and employment. It is the behaviour of households, firms, and banks, their expectations and expectation revisions, as well as variable attitudes towards risk which gain key importance.

Following Tobin, we define money/deposits and bonds as near substitutes from an investor's point of view. From these we segregate a second block, which includes all assets bought as complements to those in the first block: physical productive capital, stocks, housing/real estate, and commodities (gold, industrial metals, crude oil, and so on). These four categories are mutually complements within their block too. In the episode between 2000 and 2003 after the stock market crash, the returns of stocks and real estate were negatively correlated, dampening the otherwise possibly disastrous effect on private consumption. Gold and other commodities are traditionally the most prominent investments in times of crisis, showing a negative correlation with stock returns. All those assets with negative (or only slightly positive) return correlations are deemed complements, because they allow investors to profit from diversifying their portfolio in terms of higher returns (at a predefined portfolio risk level) or lower risk (at a constant return level).

Figure I (p. 336) shows the transmission process in a stylised form. Starting point is the well-known »Tobin pair of tongs«. We add a time scale, showing stations of the transmission process in a chronological order at different asset markets. This seems justified, because trades at the bond or stock market can be made within a second, but investments in new machines, new housing, or especially new gold mines or oil fields takes month or even years. In the upper left part of the figure, we have the substitution effects, and in the lower part the wealth effects, if the central bank creates outside money. At the end of this process, the result should be new investment in physical capital, because Tobin's Q > I. Henceforth, this original relation will be named the "productive capital $\mathrm{Q}$ «, because we 


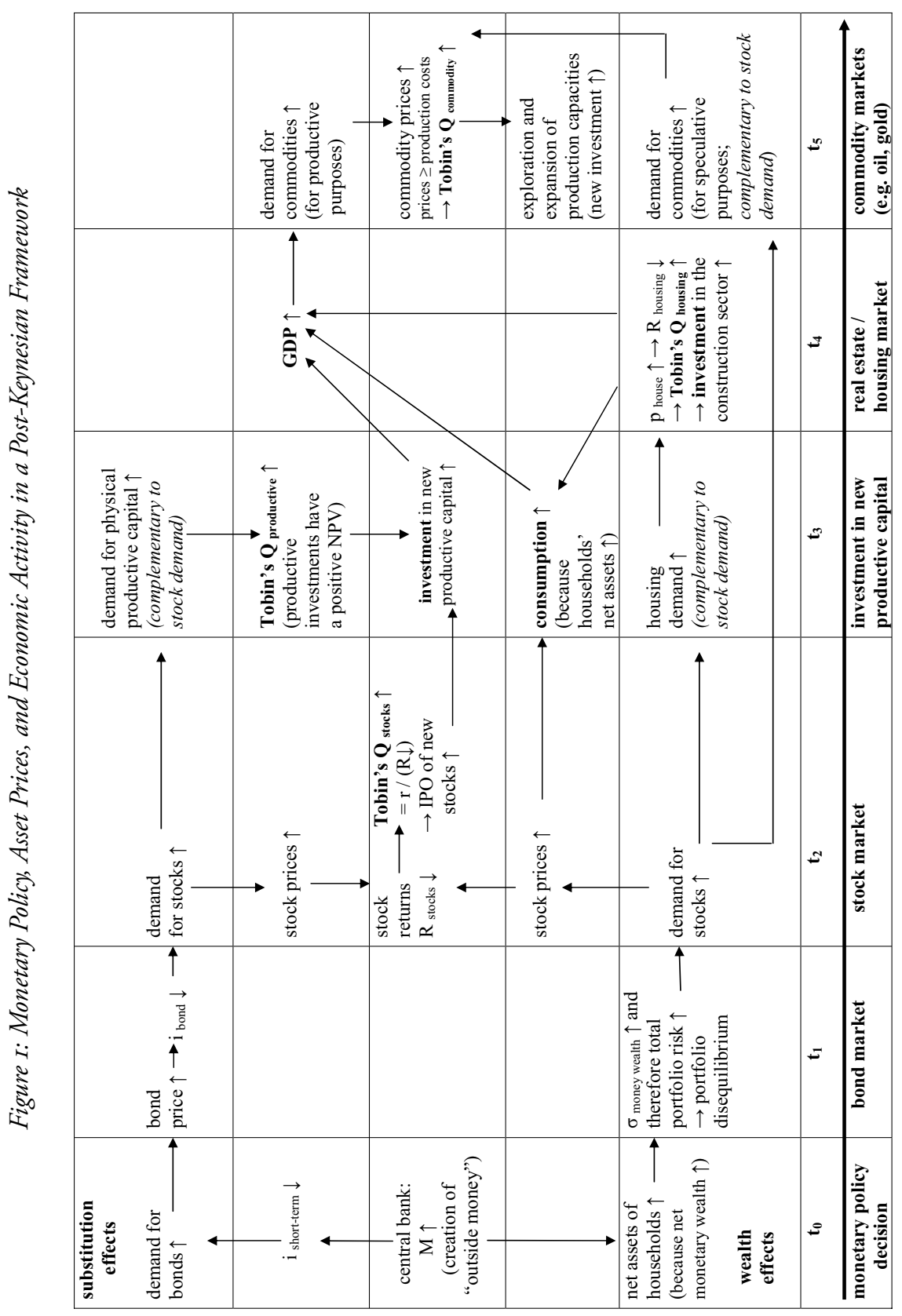


present an extended version of Tobin's portfolio theory, adding a »stock market $\mathrm{Q}$ «, "housing $\mathrm{Q}$ « and »commodity $\mathrm{Q}$ «. There are assets nowadays which played only a minor role in former times, but have gained importance and therefore should be integrated in a modern version of macroeconomic portfolio theory.

We distinguish stock market investments from investments in new productive capital, because only the latter adds to GDP growth. Initial public offerings (IPOs) of stocks are one possible form of financing new investment projects. Against this, mere stock trading without raising new firm equity is no economically productive activity. The "housing $Q$ « shows that rising house prices (at medium-term constant rents) result in lower rent returns on existing real property, and will eventually lead to new investment in the construction sector, because the rent return of new housing is higher. This again fosters GDP growth, which is also fuelled by a stronger household consumption demand in times of rising stock prices.

Finally, the "commodity $\mathrm{Q}$ « is somewhat special. It stands at the end of the transmission process, because oil or gold exploration is a time-consuming activity, i.e. some years elapse between the decision to invest in new exploitation and production capacities and the first output. For the "commodity $\mathrm{Q}$ « to become bigger than I, market prices have to exceed production costs; but because of the uncertainty regarding commodity prices in the distant future (at times when a new mining project starts hauling), yield expectations have to be substantial to engage in new long-term projects. In addition, the demand motives for commodities are twofold. On the one hand, a rising GDP will result in higher demand for productive purposes of an expanding economy. On the other hand, there is the speculative demand of investors in order to diversify their portfolios.

From a monetary policy perspective, if there are no dangers for price stability, the ECB should actively use her influence on this transmission mechanism through financial markets into the real economy to foster productive investments of firms. This process may be upset, if speculative bubbles grow big and bigger, hindering the efficient portfolio allocation according to "true« risk-return trade-offs. In the extreme, interest rate policy may become totally useless. This potential danger calls for establishing a system of ABRRs as an additional instrument of the ECB.

\section{A Proposal for Designing Asset-Based Reserve Requirements as Additional Monetary Policy Instrument in EMU}

\section{I Policy Objectives and the General Idea}

The primary objective of the ECB is to maintain price stability. Without prejudice to this, the ECB shall support the general economic policies in the Community with a view to contributing to achieve the aims of the Community (Art. IOS [I] EC Treaty). Furthermore, one of the additional tasks of the ECB is to contribute to the smooth conduct of policies pursued by competent authorities relating to the prudential supervision of credit institu- 
tions and the stability of the financial system (Art. I05 [5] EC Treaty). The primary objective of price stability should be pursued further on with the help of ECB's interest rate policy. In addition, the minimum reserve policy targeting financial and real assets could be used to take pre-emptive action against the build-up of asset price bubbles, on behalf of the goal of financial stability.

While establishing such a system of ABRRs, interest rate reactions of the ECB will be dispensable if pre-emptive monetary policy action is needed for the sake of financial or banking stability, but there are no clear signals of dangers for price stability in the short to medium term (Cournède 2006). Instead of raising her key interest rates to counteract further house price rises in some EMU countries, which surely has restrictive consequences for all credit markets (not only for mortgage loans) in all member countries, the ECB could implement higher minimum reserve rates for real estate holdings and mortgage loans referring to selected locations within EMU.

It has to be pointed out that real estate markets are special in the respect that they have local character, i.e. different rates of growth in real estate prices can be observed between the centre and the periphery of a single country, as well as between country averages. With the help of our new instrument, one of the key arguments against monetary policy reaction to asset price developments will be rendered obsolete. The welfare-reducing consequences of interest rate hikes for the economy as a whole could be avoided, which otherwise would affect other sectors and countries, where no bubble exists. This is especially true for the muted consumption demand in Germany and firms' weak propensity to invest in many EMU countries (Palley 2006).

Minimum reserves have been an element in the toolkit of the ECB since I999. Long before, they had been used by the Deutsche Bundesbank since the introduction of the German Mark in 1948, but these minimum reserves were charged on banks' liabilities (current accounts, saving accounts, time deposits, and so on), not on banks' assets. The minimum reserves have a double monetary policy aim: On the one hand, they create a need of banks and other monetary financial institutions (MFIs) for base money, leading to a stable demand for central bank money while money and credit aggregates are growing. The Deutsche Bundesbank called this "forcing the MFIs into the central bank" (Deutsche Bundesbank 1995: I28). On the other hand, the minimum reserves serve the aim of controlling banks' liquidity via variation of reserve rates. In the own words of the ECB, these two functions are the "stabilisation of money market interest rates" and the "creation or enlargement of a structural liquidity shortage« (ECB 2000: 52).

The active and central role of minimum reserves as a monetary policy instrument (in Germany) was abandoned about two decades ago. Nowadays, the reserve rates in EMU are quite low (two percent) and no distinction is made between different categories of banks' liabilities. In the I960s and I970s, the Deutsche Bundesbank actively used this instrument as a brake for money and credit expansion by the MFIs. For this purpose, it differentiated her reserve rates depending upon the liability category, amount and origin. So, the potential for using the nowadays »inactive« instrument of minimum reserves is manifold, they can target each single item of banks' balance sheets; but our aim is not the »re- 
animation" of minimum reserves on the liability side. We focus on the asset side of the balance sheet.

The main idea for these (ABRRs) was first presented in two articles by Thomas Palley (Palley 2000, 2004). There are different asset categories (real estate, stocks, bonds, commodities, and banks' credit claims) which should be subject to ABRRs, in order to prevent speculative bubbles. In what follows, we concentrate on real estate markets and mortgage financing, because a house price bubble is impossible without strong credit growth (Borio/Lowe 2004, Filc 1993). The annual growth rate of mortgage loans in EMU peaked at I2.I percent in the second quarter of 2006. The reasons for this strong credit demand are preferable interest rate conditions for mortgage loans, consumer confidence, and dynamic house price developments in many regions of EMU.

\subsection{The Starting Point for Charging Minimum Reserves and Exemptions}

Real estate markets are especially suited for implementing a system of ABRRs. This can easily be substantiated regarding the following aspects: Who buys real property, how are these transactions financed, and what is the main motive for investment?

- Households are predominantly buyers of houses and other forms of residential property, which they use for accommodation, and in countries like e.g. Germany also for renting. They are financed via mortgage loans.

- In addition, in at leastsomeEMU countrieswith boominghousing markets, households buy a second or third house for speculation, because they expect further rising prices in the near future. As far as this additional real property is financed by credit, the ABRRs would charge these investments indirectly, through the minimum reserves levied on banks granting mortgage loans in these countries.

- Firms buy real estate and industrial plants for production purposes and erecting offices. There is no speculative element in these investments, so they are of no relevance from a monetary policy point of view, and therefore exempted from minimum reserves.

- Investment (mutual) funds and Real Estate Investment Trusts (REITs) regularly acquire office equity and residential property, for generating regular returns through rental payments. They finance these acquisitions by issuing shares. If these funds and trusts were subject to ABRRs, they would have to deposit minimum reserve in relation to the real assets on their balance sheets.

- $\quad$ Private equity funds (ECB 2006c: 58ff., FSA 2006) and hedge funds are the newest and biggest players in many real estate markets. They typically finance the acquisition of their assets with not more than 15 or 20 percent equity, and 80 or 85 percent by credit. Their motive for participating in the real estate market is purely speculative. These funds would be charged twice under a system of ABRRs, if it were realised - in a second step - in its full and extensive design. Firstly, they had to deposit minimum reserves for their asset holdings. Secondly, they would be caught through 
their high leverage via heavy bank financing, because of rising credit interest rates for mortgage loans subject to minimum reserves.

- One of the advantages of residential property markets compared with financial markets is the fact that the ABRRs can be levied depending on the location of the object. In contrast to the stock market, neither the location of the credit granting bank nor of the stock exchange where the transaction is made matters.

This of course is the most desirable, the optimistic scenario, which not just implements the first step of ABRRs on banks' mortgage lending to real estate investors, but - in a second step - directly includes the real property holdings of investment (mutual) funds, REITs, private equity, and hedge funds. The main problem are the hedge funds, which collect their equity from wealthy investor in industrialised countries, but their legal structure enables them to locate the master fund (the assets itself) in an offshore, low tax financial centre. Therefore, they evade any direct regulation of central banks or regulatory authorities. Only the fund management is operating in the main global financial centres (London, New York, Frankfurt), and is subject to the financial oversight of e.g. the Financial Services Authority (FSA) in the United Kingdom (FSA 2005, ECB 2006c, Garbaravicius/ Dierick 2005, President's Working Group 1999).

Oversight allows some pressure for enhanced transparency standards, as discussed now by the $\mathrm{G}_{7}$ countries, but not comprising hedge funds into a system of ABRRs. Of course, it is mainly the hedge and private equity funds investing in residential property for speculative reasons. Therefore, without their inclusion into a system of ABRRs, financial instability and asset price bubbles sometimes seem to be inevitable. More regulative effort is needed to close loopholes for circumventing ABRRs; but without a global approach towards regulating hedge funds effectively, we have to concentrate on what is realisable today. Accordingly, our article deals with only a part of the overall problem. For these reasons, in what follows we just propose a design for the first step described above, which consists of ABRRs on bank credit.

To start with, we have to define which groups of investors and kinds of real property should be focused, and what the exemptions are. A central question for discussion is the inclusion of households acquiring residential property and financing it by taking mortgage loans. The general intention of ABRRs is fighting irrational exuberance and preventing speculative bubbles in EMU housing markets. They do not aim at increasing the overall costs of mortgage financed private housing investment. Therefore, in countries where no dangers of a bubble exist, e.g. in Germany, the reserve requirement would be zero. The burden for households via higher credit interest rates caused by ABRRs is an intervention into private property rights, so their application has to be restricted to a minimum, which is unavoidable to serve the goal of financial stability.

Nevertheless, in countries like e.g. Spain there is no other instrument in sight, which may be able to tackle the real estate bubble effectively. Since July 2000, Spain has experimented with some new and innovative instruments in order to oppose excessive risk taking and problem loans within the Spanish banking sector. These instruments of prudential 
regulation aimed at dampening the pro-cyclicality of the financial sector (Fernández de Lis et al. 2000, Caruana 2005, Jiménez/Saurina 2005). The "dynamic loan loss provisioning « shares some features of ABRRs and follows a macroeconomic stability approach, too. The main advantage of ABRRs versus loan loss provisions is its application to all MFIs, not only those which show the most imprudent credit expansion. They directly apply to banks' assets, not only new credit granted, and not via the detour of provisions in the profit and loss account. ABRRs have to be deposited directly at the central bank.

Even real estate professionals confess the dangers ahead, since in some EMU countries housing has become a merchandise or commodity like many others. Traditionally, owner occupied housing has always been recognised mainly as a consumption good. Now it has become more and more an investment good (Smith 2005, Attanasio et al. 2005). Therefore, it would make sense to support the introduction of ABRRs in EMU with well-designed tax systems for real estate capital gains (ECB 2003: $35 \mathrm{ff}$.). Tax exemptions should only be possible if owner occupiers sell their house not earlier than ten years after acquisition.

Exemptions from the minimum reserve requirements should be made for mortgage loans to younger people financing their first home. Bank credit for the aim of constructing new real property for owner occupiers should not be subject to reserve requirements either, even in those countries where otherwise ABRRs are charged on investors. This may also apply to pension funds investing in real estate, where the shares cannot be sold before reaching the age of retirement. Of course, one has to bear in mind that defined contribution pension schemes investing substantial parts of their enormous liquidity in real estate might at least partly explain the rapid price increases in some EMU housing markets. On the other hand, households buying a second or third house for speculation (or renting) would be charged. With the help of this new instrument, in countries like e.g. Spain the house price boom fuelled by private investor demand could be slowed down considerably (Ayuso/Restoy 2003 and 2006, Martinez Pagés/Maza 2003).

\section{House Price Bubble Indicators and the Level of Minimum Reserve Rates}

As a prerequisite for fighting house price bubbles effectively, there are two main questions to be answered: What are the best indicators signalling a divergence between fundamental and market value of residential property in due time; and what is the appropriate level of minimum reserve rates counteracting the formation of speculative bubbles? In this section we try to present some deliberations and hopefully promising results for further study and monetary policy discussion. The following indicators should be regarded as a possible set of early warning signals for house price bubbles, which in combination allow the choice of adequate reserve rates for ABRRs:

- Indicator I: The average annual rise in residential property prices (since the start of EMU in 1999) should not surpass the growth of per-capita GDP markedly. 
- Indicator 2: Annual mortgage credit growth rates should not clearly exceed the growth of per-capita GDP for many subsequent years.

- Indicator 3: In those EMU countries, where the Anglo-Saxon system of mortgage equity withdrawal (MEW) is a common feature of market-based banking systems, the total amount of MEW should not become noticeable positive, i.e. a situation where all national households together do not add new equity to their housing.

- Indicator 4: The gross value added in the construction sector (as a percentage of total gross value added in the economy) should not markedly exceed the EMU average, and it should remain fairly constant over time, i.e. showing no long-lasting upward trend.

- Indicator 5: Household "net interest expenditure« on mortgage loans should not deliver false incentives, letting them undertake unsustainable real estate investments (on a loan-to-value basis). Therefore, the real interest rate on mortgage loans (after subtracting the national HICP inflation rate) should be distinctively greater than zero. Moreover, the real interest rate on mortgage loans should be the higher, the higher national GDP growth is.

Current values for the indicators I and 2 are presented in table I. From I999 until the end of 2005 the per-capita GDP shows the highest annual growth rate in Ireland, which was 60.8 percent in total, or an average of 8.2 percent p.a. At the lower end stands Germany with a total of I0.9 percent, or I.7 percent p.a. Correspondingly, house prices rose by I3.5 percent p.a. in Ireland, whereas in Germany they were falling by o.6 percent p.a. Of course, the higher growth of GDP per capita in Ireland allows for stronger house price growth, but not as much as it has been the case since 1999. This judgement is validated with the help of values for indicator I. Since the start of EMU, there are seven countries (led by Spain and France) where annual house price rises exceed the growth of per-capita GDP by more than four percentage points. So, we preliminary identify these countries as being candidates for overvalued real property markets. This calls for counter-measures, if the results are confirmed by some further critical values of other indicators. Of course, these average annual price rises may be different when calculated at a local level, instead of the national level. As a general rule, price rises in urban areas, especially in the capital, surpass those in rural areas.

For the time being, indicator 2 only has supplemental information status. Greece shows the highest mortgage credit growth rate (after correction for per-capita GDP growth). Nevertheless, this indicator value carries not too much information content, because Greece joined EMU in 200I, and the convergence process seems to be not yet finished (ECB 2006b: 44). In addition, Greece has by far the lowest household indebtedness of all EMU countries (about ten percent of GDP, compared with 65 percent in Germany; according to ECB 2006b: 43); but within the next few years, this catching-up will come to an end, and indicator 2 then may deliver better early warning signals in an integrated EMU financial and banking market. 


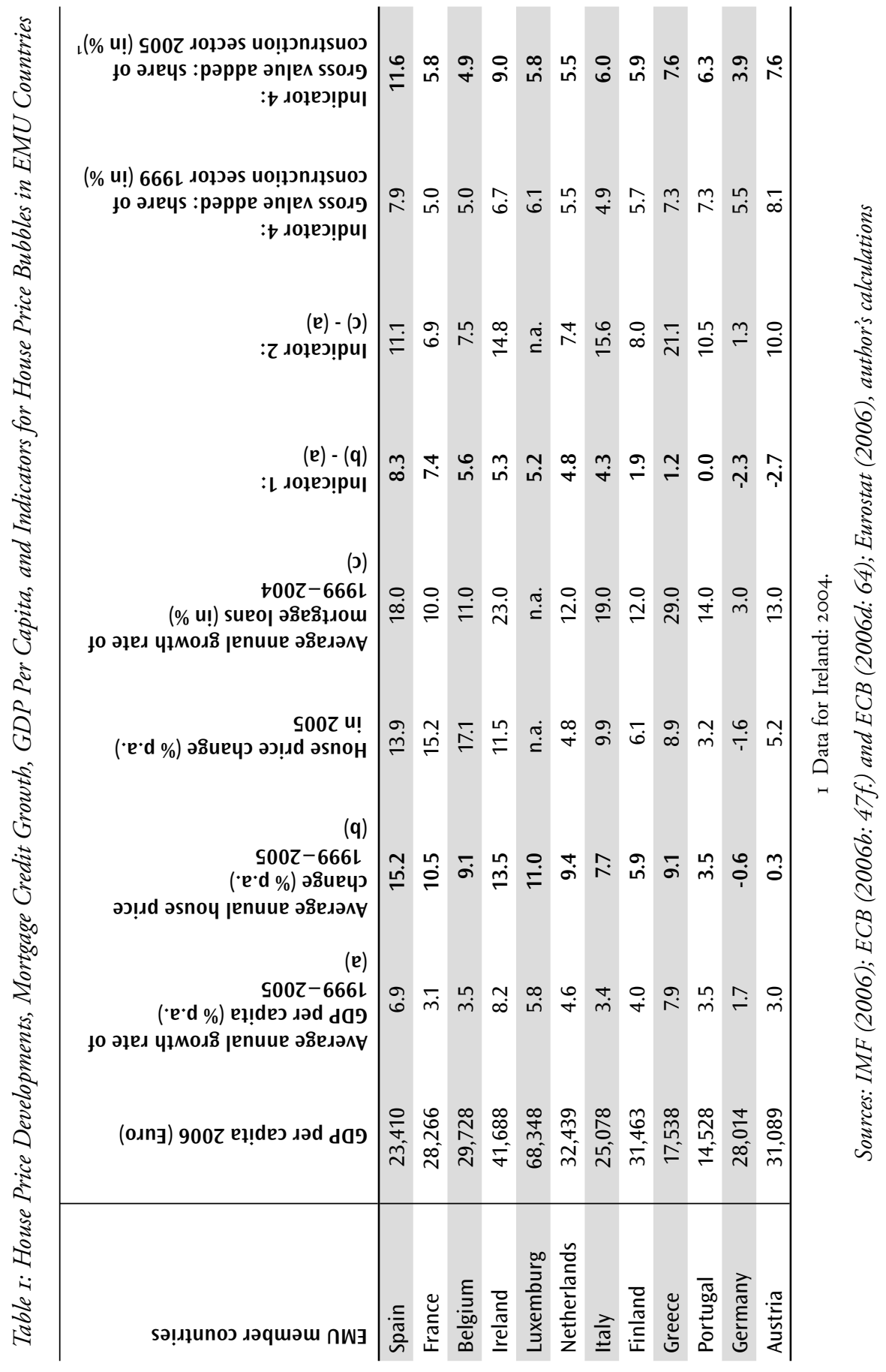


Indicator 3 has a double function: On the one hand, it should point towards dangers for overall price stability, stemming from strong private consumption demand fuelled by mortgage equity withdrawal (MEW). On the other hand, a rising volume of MEW indirectly informs about dangers caused by rising loan-to-value ratios rooted in households' expectations of accelerating house price rises. An OECD study (Catte et al. 2004) points out that MEW is a more or less typical Anglo-Saxon phenomenon, playing a dominant role in the United Kingdom, the United States, and Australia. Within the European Union, MEW is found in those countries that are not members of EMU (UK, Denmark, and Sweden). Among EMU countries, until recently only the Netherlands have shown positive MEW values, i.e. the increase in house financing (net mortgage lending) has exceeded households' housing investments (Smith 2004, Benito/Power 2004).

This is of particular relevance because the OECD concludes that the higher the volume of MEW, the higher is the marginal propensity to consume out of housing wealth. Since 2003, France is the second EMU country showing rising values for indicator 3 . Until the end of the I990s, the French MEW indicator varied between -4 and -5 percent of disposable income, but has now reached the zero-percent frontier. This goes hand in hand with house price rises accelerating to Is percent during the year 2005 (Sobczak 2006).

Indicator 4 regards gross value added in the construction sector. For countries with comparable levels of economic development, there should be only minor variations in this construction share over the business cycle. If a real property bubble starts to grow and later perhaps bursts, the picture will be quite different. We take the construction boom following German unification as a benchmark for a suboptimal resource allocation. The share of gross value added in construction (in relation to total German gross value added) started with 5.6 percent in the first quarter of I99I and reached a top at 7.2 percent in the last quarter of 1994 . Since then, it has been declining steadily, now stabilising at values around four percent. The data for other EMU members indicate that Germany is by now the country with the lowest construction share. The EMU average from 1995 to 2005 varied between 5.6 percent and 6.3 percent. Individual country data are shown again in table I.

By far the highest value for indicator 4 is found in Spain with II.6 percent in 2005. It surmounts the top reached after German unification by more than four percentage points. Until 1999, the Spanish construction share lay below 8 percent; so the latest data could be interpreted hinting at a potential house price bubble, despite the fast-growing Spanish economy. Furthermore, the construction share of nine percent in Ireland calls for monetary policy vigilance for the sake of banking and financial stability; whereas the 7.6 percent in Greece are at least partly due to the above mentioned convergence process still under way (Austria has a construction share of this magnitude, too).

Finally, indicator 5 shows household "net interest expenditure (NIE) on mortgage loans. For calculation we take the ECB data on mortgage loans to households with interest rates fixed for at least ten years, and then subtract the national HICP inflation rate in each EMU country. In 2004, the real interest rate was I.6 percent in Spain, 2.9 percent in Germany, and 4.6 percent in Finland. To eliminate outliers, we take a three year average (2003-05). The »real rate" presents a first hint for the divergence of house financing costs 
within EMU. For checking the sustainability of household mortgage financing, the »real rate " has to be compared with the development of households' disposable income. Because GDP growth rates substantially vary within EMU, indicator 5 subtracts - in a second step the average annual GDP growth rate in the years 2003-05 from the average real interest rate. The higher GDP growth, the higher normally are annual wage increases, and therefore the easier households can afford buying mortgage financed residential property, even regarding rising house prices.

Table 2 (p. 346) presents the indicator values for EMU countries, which allow for the identification of three groups. The highest NIE had to be paid in Germany, Portugal, Italy, and the Netherlands. They took values between I.6 percent and 2.4 percent. These NIE seem to be sufficient for securing stable house price developments. It follows a second group of countries with indicator values around one percent. Within this group, no clear inference with respect to house price misalignments is possible, because it includes countries with rapidly rising house prices (France and Belgium), as well as Austria and Finland with only moderate price rises. Here again, a cross-checking with the additional four indicators is needed. In the third group (Spain, Ireland, Luxemburg, and Greece) the NIE took negative values, i.e. GDP growth rates surpassed real mortgage interest rates. Among them are the countries showing the highest annual mortgage credit growth rates (see table $\mathrm{I}$ ). Therefore, indicator 5 signals dangers of housing markets expanding too much and too fast in these countries.

For estimating the degree of necessary monetary policy reaction, we develop an early warning system comprising the five aforementioned indicators. A scoring model is presented which weights the indicators according to their importance, and it shows for each indicator category those EMU countries susceptible to house price misalignments (see table 3, p. 347).

Indicator $\mathrm{I}$ is granted the highest weight. Spain and France, the countries where average annual house price rises exceeded per-capita GDP growth by more than seven percentage points, get a score of three, i.e. they are put in the highest "peril group « III. Belgium, Ireland, and Luxemburg, with values of indicator I below seven percent, but above five percent fall into peril group II; Italy and the Netherlands with values below five percent, but well above two percent in peril group I. All other countries get a zero score. The following indicators only differentiate two peril groups, and indicator 3 just asks for the existence of MEW (score: zero/one). All in all, a maximum of ten scoring points is possible. The higher the score, the greater are the dangers of a house price bubble. Indicator 2 for mortgage credit growth (in relation to GDP per capita growth) refers Greece, Italy, and Ireland into peril group II, because of their indicator values around Is percent and above. Peril group I consists of Spain, Portugal, and Austria, according to values exceeding ten percent, but lying markedly below is percent.

Indicator 3 claims dangers resulting from mortgage equity withdrawal only for France and the Netherlands. Indicator 4 shows that the share of the Spanish construction sector of II.6 percent by far exceeds the EMU average (peril group II); but the Irish value of nine percent reminds of possible dangers, too (peril group I). The threshold values for the 
s00z- $-\varepsilon 00 z$

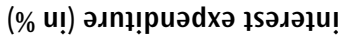
ןәи әвеләке : $\varsigma$ лорез!рu|

(כ) - (孔) (\% u!) S00Z әлnџ!puədxə

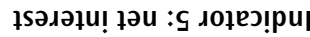

(q) - (ә)

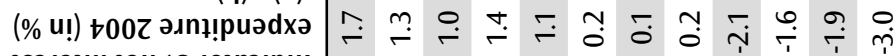

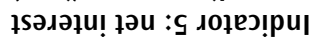

(e) - (p) (\% u!) ع00Z әлn!!puədxə

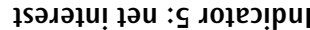

(y)

(\% u!) s00Z әјеג

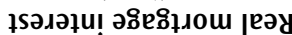

(ว) (\% u!) †00Z әІЕА

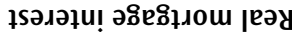

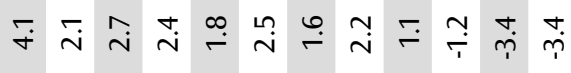
(马)

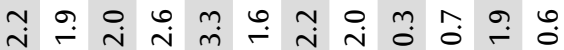
)

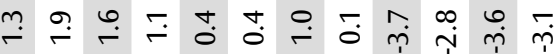

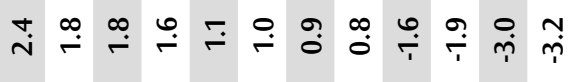

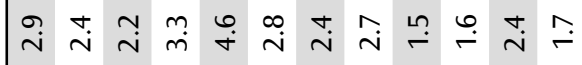

(p)

(\%u!) ع00Z әреג

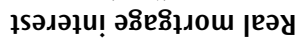

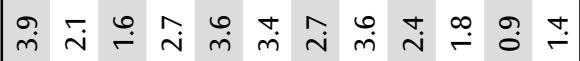
(\%) s00Z-ع00Z әرеג

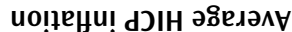

(ग)

(ว8̊иеу \% ןеnuu s00Z daפ ןеәу

(q)

(ว8̊иeчว \% ןеnuue)

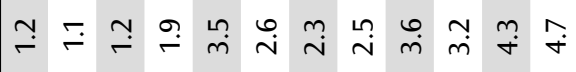
†00Z daJ ןеәу

(e)

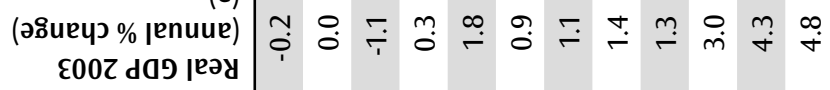

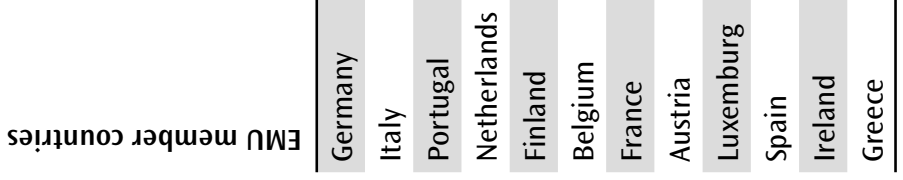


Table 3: A Scoring Model Delivering Early Warning Signals of House Price Bubbles in EMU Countries and the Suggested Level of Minimum Reserve Rates According to a System of ABRRs

\begin{tabular}{|c|c|c|c|c|c|c|c|c|}
\hline 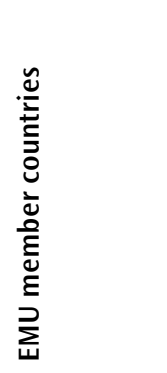 & 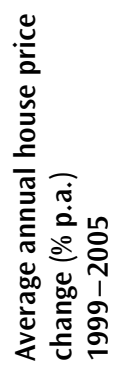 & 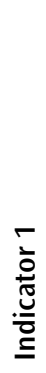 & 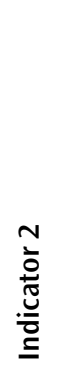 & 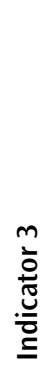 & 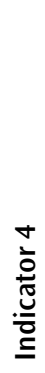 & 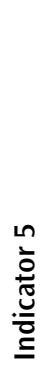 & 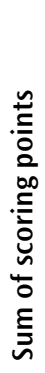 & 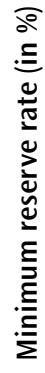 \\
\hline Spain & 15.2 & 3 & 1 & & 2 & 2 & 8 & 30 \\
\hline Ireland & 13.5 & 2 & 2 & & 1 & 2 & 7 & 30 \\
\hline France & 10.5 & 3 & & 1 & & 1 & 5 & 20 \\
\hline Luxemburg & 11.0 & 2 & & & & 2 & 4 & 10 \\
\hline Greece & 9.1 & & 2 & & & 2 & 4 & 10 \\
\hline Belgium & 9.1 & 2 & & & & 1 & 3 & 10 \\
\hline Italy & 7.7 & 1 & 2 & & & & 3 & 10 \\
\hline Netherlands & 9.4 & 1 & & 1 & & & 2 & 0 \\
\hline Austria & 0.3 & & 1 & & & 1 & 2 & 0 \\
\hline Finland & 5.9 & & & & & 1 & 1 & 0 \\
\hline Portugal & 3.5 & & 1 & & & & 1 & 0 \\
\hline Germany & -0.6 & & & & & & 0 & 0 \\
\hline
\end{tabular}

Source: See Tables 1 and 2, author's calculations

three groups formed according to indicator 5 were just mentioned above. The four countries with negative NIE fall into peril group II; the subsequent four countries with only slightly positive indicator values fall into peril group I.

Adding up all the scores delivers a clear picture with regard to EMU countries susceptible to house price bubbles (see table 3). Spain reaches eight out of ten possible scoring points, Ireland seven, and France five. At the lower end there is Germany with a zero score, as well as Portugal and Finland with only one score. All in all, Spain and Ireland should be the countries with the highest minimum reserve rate of 30 percent on mortgage loans, according to a system of ABRRs. For France, we recommend a reserve rate of 20 percent. In the countries with three or four scoring points (Luxemburg, Greece, Belgium, and Italy) minimum reserves should be introduced at a rate of ten percent.

The minimum reserve rates proposed here are suitable for rendering mortgage financed speculative real estate investment more costly. A small algebraic exercise may verify this. If the nominal mortgage interest rate is 4.60 percent, a minimum reserve rate of 20 percent would raise the financing costs by more than one percentage point to 5.75 percent. 
Applying a reserve rate of even 30 percent, the mortgage interest rate rises to 6.57 percent. It seems to be evident that such a clear-cut monetary policy signal is able to stop further house price rises in due time. As a consequence, house prices do not have to fall drastically, because per-capita GDP growth in Spain and Ireland is still remarkable. Furthermore, it should be kept in mind, that a minimum reserve rate as high as 25 percent does nothing more than just compensating for the real interest rate differential between Spain and Germany, when the inflation rate is 2.6 percent in the former, and I.I percent in the latter country (as it was the case in October 2006).

Hopefully, within the next few years there is enough time to gain experience with this new instrument of monetary policy in EMU. At a later stage it has to be deliberated, if for reasons of simplification the now existing system of minimum reserves on deposits can be terminated. The precondition for this will be a stable and permanent "compulsory demand for base money " (in the words of the Deutsche Bundesbank I995: I28), stemming only from the asset side of banks' balance sheets.

\section{Conclusion}

The system of ABRRs presented here is supposed to influence the ongoing debate on the pros and cons of monetary policy reaction to severe house price overvaluation. It allows pursuing two complementary goals by using two different monetary policy instruments. The ECB's primary objective of price stability should be targeted further on with the help of interest rate policy. Beyond this, the system of ABRRs may aim to reach the subordinate goal of financial stability (laid down in Art. I05 [5] of the EC Treaty) as well, which comprises taking pre-emptive measures against real estate bubbles.

Thereby the ECB's interest rate reactions are regularly dispensable, if dangers for financial stability substantiate, which will be mirrored in higher HICP inflation only in the long run. Interest rate rises necessitated by rising house prices in only some EMU countries (in which they go hand in hand with rising inflation), causing EMU-wide restrictive effects, could be replaced by ABRRs narrowly targeting real estate markets in selected countries. Therefore, one of the main counterarguments against monetary policy intervention in asset markets could be invalidated. But the ABRRs system is not only fitted for fighting house price bubbles, it serves the aim of banking stability, too. The ABRRs on mortgage credit would supplement MFIs equity requirements under Basel II regulations. The reserve requirements should function as an automatic stabiliser and a "credit expansion brake« in economic boom periods.

It was Charles Kindleberger, who - in this sense - recognised as early as 1995:

"When speculation threatens substantial rises in asset prices, with a possible collapse in asset markets later, and harm to the financial system, or if domestic conditions call for one sort of policy, and international goals another, monetary authorities confront a dilemma calling for judgment, not cookbook rules of the game." (Kindleberger 1995: 35) 
The implementation of an ABRR system should progress step by step. In the first step, which was described extensively in this article, MFIs' mortgage loans are subject to minimum reserve rates between Io percent and 30 percent in those countries, for which the five here presented indicators signal dangers of a real estate bubble. As a second step, left to future research, the balance sheet assets of investment (mutual) funds and other financial investors (hedge funds, private equity funds) should be directly charged with similar ABRRs. This calls for international cooperation of central banks and financial oversight authorities as an unalterable prerequisite.

\section{References}

Altissimo, Filippo/Georgiou, Evaggelia/Sastre, Teresa/Valderrama, Maria T./Sterne, Gabriel/ Stocker, Marc/Weth, Mark A./Whelan, Karl/Willman, Alpo (2005): Wealth and Asset Price Effects on Economic Activity, ECB Occasional Papers, No. 29

Attanasio, Orazio/Blow, Laura/Hamilton, Robert/Leicester, Andrew (2005): Consumption, House Prices and Expectations, Bank of England Working Paper, No. 27I

Ayuso, Juan B./Restoy, Fernando (2003): House Prices and Rents: An Equilibrium Asset Pricing Approach, Banco de España Working Paper, No. 304

Ayuso, Juan B./Restoy, Fernando (2006): House Prices in Spain: Is the Evidence of Overvaluation Robust?, in: Banco de España Economic Bulletin, No. July, pp. 3-9

Benito, Andrew/Power, John (2004): Housing Equity and Consumption: Insights from the Survey of English Housing, in: Bank of England Quarterly Bulletin, Vol. 44, No. 3 , pp. 302-309

Borio, Claudio E.V./Lowe, Philip W. (2004): Securing Sustainable Price Stability: Should Credit Come Back from the Wilderness?, BIS Working Paper, No. I57

Caruana, Jaime (2005): Monetary Policy, Financial Stability and Asset Prices, Banco de España Working Paper, No. 507

Catte, Pietro/Girouard, Nathalie/Price, Robert/André, Christophe (2004): The Contribution of Housing Markets to Cyclical Resilience, in: OECD Economic Studies, No. 38, pp. $125-\mathrm{I} 56$

Cournède, Boris (2005): House Prices and Inflation in the Euro Area, OECD Economics Department Working Paper, No. 450

Deutsche Bundesbank (1995): Die Geldpolitik der Bundesbank, Frankfurt on the Main: Deutsche Bundesbank

Deutsche Bundesbank (2006): Monthly Bulletin, No. I2

ECB (2000): The Single Monetary Policy in Stage Three, General Documentation on Euro System Monetary Policy Instruments and Procedures, Frankfurt on the Main: ECB

ECB (2002): The Stock Market and Monetary Policy, in: Monthly Bulletin, No. 2, pp. 39-52

ECB (2003): Structural Factors in the EU Housing Market, Frankfurt on the Main: ECB

ECB (2005): Asset Price Bubbles and Monetary Policy, in: Monthly Bulletin, No. 4, pp. 47-6o

ECB (2006a): Assessing House Price Developments in the Euro Area, in: Monthly Bulletin, No. 2, pp. 55-70 
ECB (2006b): Annual Report 2005, Frankfurt on the Main: ECB

ECB (2006c): Financial Stability Review, Frankfurt on the Main: ECB

ECB (2006d): Monthly Bulletin, No. 6

ECB (2006e): Monthly Bulletin, No. I2

Eurostat (2006): Yearbook 2005, Luxembourg: Eurostat

Fernández de Lis, Santiago/Martinez Pagés, Jorge/Saurina, Jesus (2000): Credit Growth, Problem Loans and Credit Risk Provisioning in Spain, Banco de España Working Paper, No. 18

Filc, Wolfgang (1993): Credit as Intermediate Target of Monetary policy, in: Frowen, Stephen F. (ed.), Monetary Theory and Monetary Policy, New York: St. Martin's Press, pp. 188-216

Financial Services Authority [FSA] (2005): Hedge Funds: A Discussion of Risk and Regulatory Engagement, Discussion Paper, No. 4

Financial Services Authority [FSA] (2006): Private Equity: A Discussion of Risk and Regulatory Engagement, Discussion Paper, No. 6

Garbaravicius, Tomas/Dierick, Frank (2005): Hedge Funds and their Implications for Financial Stability, ECB Occasional Paper, No. 34

HM Treasury (2003): Housing, Consumption and EMU, London: HM Treasury

IMF (2006): World Economic Outlook Database

Jiménez, Gabriel/Saurina, Jesus (2005): Credit Cycles, Credit Risk and Prudential Regulation, Banco de España Working Paper, No. 53I

Kindleberger, Charles (1995): Asset Inflation and Monetary Policy, in: BNL Quarterly Review, No. 192, pp. 17-37

Martinez Pagés, Jorge/Maza, Luis A. (2003): Analysis of House Prices in Spain, Banco de España Working Paper, No. 307

OECD (2005): Recent House Price Developments: The Role of Fundamentals, in: OECD Economic Outlook, No. 78, pp. 193-234

Palley, Thomas (2000): Stabilizing Finance: The Case for Asset-Based Reserve Requirements, Report in the Financial Markets and Society Series, Philomont, VA.: Financial Markets Centre

Palley, Thomas (2004): Asset-Based Reserve Requirements: Reasserting Domestic Monetary Control in an Era of Financial Innovation and Instability, in: Review of Political Economy, Vol. 16, No. I, pp. 43-58

Palley, Thomas (2006): Currency Unions, the Phillips Curve, and Stabilization Policy: Some Suggestions for Europe, in: Intervention. Journal of Economics, Vol. 3, No. 2, pp. 35I369

President's Working Group on Financial Markets (1999): Hedge Funds, Leverage, and the Lessons of Long-Term Capital Management, Washington D.C.

Smith, Jackie/Vass, Jennet (2004): Mortgage Equity Withdrawal and Remortgaging Activity, in: Council of Mortgage Lenders Housing Finance, No. 63, pp. 8-2I

Smith, Susan J. (2005): Banking on Housing? Speculating on the Role and Relevance of Housing Wealth in Britain - Inquiry into Home Ownership 2010 and Beyond, Paper prepared for the Joseph Rowntree Foundation, Durham University 
Sobczak, Nicolas (2006): France Vulnerable to a Housing Downturn, in: Goldman Sachs European Weekly Analyst, Vol. 6, No. 43, pp. 4-7

Tobin, James (1969): A General Equilibrium Approach to Monetary Theory, in: Journal of Money, Credit, and Banking, Vol. I, No. I, pp. I5-29

van den Noord, Paul (2006): Are House Prices Nearing a Peak? A probit analysis for I7 OECD countries, OECD Economics Department Working Paper, No. 488 
